\title{
Benthic Metabolism in Fluvial Sediments with Larvae of Lampetra sp.
}

\author{
Nerijus Nika ${ }^{1, *}{ }^{\oplus}$, Mindaugas Zilius $^{1}\left(\mathbb{0}\right.$, Tomas Ruginis $^{1}$, Gianmarco Giordani ${ }^{2}$, Kasparas Bagdonas ${ }^{1}$, \\ Sara Benelli ${ }^{2,3}$ and Marco Bartoli ${ }^{1,2}$ (D) \\ 1 Marine Research Institute, Klaipeda University, 92294 Klaipeda, Lithuania; \\ mindaugas.zilius@jmtc.ku.lt (M.Z.); tomas.ruginis@apc.ku.lt (T.R.); kasparas.bagdonas@gmail.com (K.B.); \\ marco.bartoli@unipr.it (M.B.) \\ 2 Department of Chemistry, Life Science and Environmental Sustainability, Parma University, \\ 43124 Parma, Italy; gianmarco.giordani@unipr.it (G.G.); sara.benelli@unipr.it (S.B.) \\ 3 Water Research Institute (CNR-IRSA) National Research Council, 28922 Verbania Pallanza, Italy \\ * Correspondence: nerijus.nika@apc.ku.lt
}

check for updates

Citation: Nika, N.; Zilius, M.; Ruginis, T.; Giordani, G.; Bagdonas, K.; Benelli, S.; Bartoli, M. Benthic Metabolism in Fluvial Sediments with Larvae of Lampetra sp. Water 2021, 13, 1002. https://doi.org/ 10.3390/w13071002

Academic Editor: Thomas Hein

Received: 11 March 2021

Accepted: 5 April 2021

Published: 6 April 2021

Publisher's Note: MDPI stays neutral with regard to jurisdictional claims in published maps and institutional affiliations.

Copyright: (c) 2021 by the authors. Licensee MDPI, Basel, Switzerland. This article is an open access article distributed under the terms and conditions of the Creative Commons Attribution (CC BY) license (https:// creativecommons.org/licenses/by/ $4.0 /)$.

\begin{abstract}
Lampreys spend their larval stage within fine sand fluvial sediments, where they burrow and act as filter feeders. Lamprey larvae (ammocoetes) can significantly affect benthic-pelagic coupling and nutrient cycling in rivers, due to high densities. However, their bioturbation, feeding and excretion activities are still poorly explored. These aspects were investigated by means of laboratory incubations of intact sediments added with ammocoetes and of animals alone. Oxygen respiration, nutrient fluxes and excretion rates were determined. Individual ammocoete incubations suggested that biomass-specific oxygen consumption and ammonium, reactive phosphorus and silica excretion were size-dependent, and greater in small compared to large individuals. The comparison of ammocoetes metabolic rates with rates measured in intact sediments revealed that ammocoetes activity decreases significantly when they are burrowed in sediments. Furthermore, results suggest that a major fraction of ammonium excreted by ammocoetes was assimilated by benthic microbes or microalgae to overcome in situ N-limitation. Alternatively, part of the excreted ammonium was oxidized and denitrified within sediments, as nitrate uptake rather increased along with ammocoetes density. Ammocoetes excreted reactive phosphorus and silica but such production was not apparent in bioturbated sediments, likely due to microbial or microalgal uptake or to immobilization in sediments.
\end{abstract}

Keywords: ammocoetes; sediments; bioturbation; metabolism; fluxes; engineering species

\section{Introduction}

Sediment bioturbation is an extensively studied subject, both in marine and freshwater systems [1-5]. It consists of a variety of processes affecting sediment physical structure and biogeochemistry and is grouped into two main actions: the reworking of particles and the ventilation of burrows [2]. The reworking of particles occurs during burrowing activities and includes the mixing of old and recent organic matter, the ingestion of sediments and the production of biodeposits. All these processes may determine a priming effect on the mineralization of sedimentary organic matter pools, in particular of their refractory fractions. This results in nutrient recycling and contrasts their burial. Burrows ventilation introduces oxygen $\left(\mathrm{O}_{2}\right)$ and sometimes nitrate $\left(\mathrm{NO}_{3}{ }^{-}\right)$-rich water within sediments, at depths where these electron acceptors are generally depleted [6,7]. Oxygen and $\mathrm{NO}_{3}{ }^{-}$ diffuse through burrow walls and create oxidized niches, producing multiple biogeochemical consequences, such as the oxidation of chemically reduced compounds (e.g., metals, sulphides or methane), nitrogen $(\mathrm{N})$ removal via coupled nitrification and denitrification and phosphorus $(\mathrm{P})$ precipitation $[8,9]$. 
Microbioturbation by small organisms as meiofauna (e.g., organisms with body size $<1 \mathrm{~mm}$ ) was demonstrated to increase organic matter mineralization and $\mathrm{CO}_{2}$ fluxes [10] and $\mathrm{N}$ removal via denitrification [11]. However, most bioturbation studies have addressed the role of macrofauna (e.g., organisms with body size $>1 \mathrm{~mm}$ ); benthic macrofaunal communities consist of organisms characterized by different functional groups, each colonizing different sediment horizons, with specific bioturbation mode and feeding strategy [12]. Bioturbation by macrofauna was demonstrated to produce important effects on benthic metabolism, significantly enhancing mineralization rates and benthic-pelagic coupling or facilitating the growth of primary producers $[13,14]$. Bioturbation is performed also by large vertebrate organisms as fish when they resuspend sediments during feeding, hiding or reproduction $[3,4]$. Cyprinids, for example, are known to feed on sediment macrofauna as snails and chironomids and determine particles resuspension and nutrient mobilization in the water column [15]. Egg hiders like salmonids or lampreys, during the gravel nest digging, may significantly affect bottom properties $[4,16,17]$. Having very close sympatric distribution in rivers and streams of the Northern Hemisphere, salmonids and lampreys with their coarse-substrate bioturbation may produce profound ecological effects on their reproduction conditions [18] and on the stream ecosystems $[4,16]$.

Lampreys are acknowledged as burrowing ecosystem engineers, not only at the adult spawner stage [16], but also during the whole larval stage $[19,20]$, which is very unique within vertebrates. Lampreys have a 3-8 year larval stage in between the free embryonic and metamorphosis phases during which they are called ammocoetes and spend most of their time burrowed in the soft sediments of streams and rivers [21]. Ammocoetes burrow by inserting their head into the sediments with vigorous contractions of the tail [22]. Elective substrates are made of fine sands or coarse organic matter, allowing burrow construction, water exchange and protection against predators $[23,24]$. Ammocoetes feed on particulate matter suspended in the water column. They are thus able to circulate the water through their mouth and perform filter-feeding activity. This is a very specific behavior of a vertebrate: ammocoetes burrow as any polychaete and feed on suspended matter as mollusks. While in their burrow, larvae exploit water flow through their branchial chamber for the provision of food, respiratory needs and excretion of metabolic wastes [22]. Due to the length of their larval stage, good-quality burrowing substrates are important for the vitality of lamprey populations. The ammocoetes abundance generally displays positive correlation with soft sediment, organic matter, low flow and low depth, which characterize streams marginal habitats [25-27]. Lampreys larvae are able to affect via their bioturbation, the sediment physical structure, oxidation status and microbial communities of these marginal habitats $[22,28]$. Ammocoetes may also modify nutrient dynamics at the sedimentwater interface during their burrowing phase, but the biogeochemical effects, extent and significance are still poorly studied $[19,20]$. The understanding of the effects produced by the ammocoetes during their burrowing phase is consequently of interest both in management-conservation and in benthic biogeochemistry-river functioning perspectives.

In this study we measured benthic processes in sediments added with lamprey larvae as a first assessment of their contribution to benthic respiration and nutrient cycling. We focused on the dissolved inorganic forms of nitrogen $\left(\mathrm{NH}_{4}{ }^{+}\right.$and $\left.\mathrm{NO}_{3}{ }^{-}\right)$, silica $\left(\mathrm{SiO}_{2}\right)$ and phosphorus $\left(\mathrm{PO}_{4}{ }^{3-}\right)$ as these chemical species represent the main nutrients that support the growth of phytoplankton and microphytobenthos. Any variation in their biogeochemical cycle, either from external pressures or resulting from the activity of the macrobiota, may produce deep impacts in the functioning of aquatic ecosystems. Ammocoetes respiration $\left(\mathrm{O}_{2}\right.$ consumption) and excretion rates (dissolved nitrogen, phosphorus and silica release) were also quantified to analyze the contribution of lamprey larvae metabolism to benthic processes. This study falls within investigations addressing the functional role of organisms that enhance nutrient recycling and bentho-pelagic coupling and might have an important role in sustaining primary and secondary production, and in general river functioning [29]. Such an investigation is urgent as lamprey larvae abundance is declining in many areas, 
and the net loss of ecosystem functions associated to the disappearance of these organisms is unknown.

Deep alterations of riverine ecosystems, including water abstraction, discharge regulation, hydropeaking, dredging, impoundment, embankment and eutrophication have decreased larval habitats, and impacted lamprey populations [25,30,31]. The ecological niche of lampreys, and of ammocoetes in particular, is still poorly explored and more information on the interactions between larvae and river benthic and pelagic compartments is needed to understand the biogeochemical role of these organisms and to improve the recovery of lamprey populations.

\section{Materials and Methods}

\subsection{Sampling Procedure and Microcosms Set-Up}

Ammocoetes of Lampetra sp. were collected in July 2015 from the River Šventoji located in the region of western Lithuania $\left(56^{\circ} 03^{\prime} \mathrm{N}, 21^{\circ} 11^{\prime} \mathrm{E}\right)$ (Figure 1). At the sampling site, sediments were colonized by a variety of submersed, floating leaved and emergent macrophytes; but large patches devoid of vegetation were also found. The width of the wet section at the study site was 5-6 m, the maximum depth was $1 \mathrm{~m}$ and the average water velocity of the whole water column, measured at several transects with a current meter (Flow Probe FP101, Global Water Instrumentation, College Station, TX, USA) was $0.1 \pm 0.1 \mathrm{~m} \mathrm{~s}^{-1}$. The river water was yellowish, likely due to elevated concentrations of dissolved organic matter, whereas dissolved inorganic nutrient concentrations were low, with silicon ( $\mathrm{Si}$ ) in excess to $\mathrm{N}$ and $\mathrm{P}$. Ammonium and $\mathrm{NO}_{3}{ }^{-}$concentrations averaged $3.1 \pm 0.9$ and $6.4 \pm 1.7 \mu \mathrm{M}$, respectively. Soluble reactive phosphorus and $\mathrm{SiO}_{2}$ averaged $1.2 \pm 0.1$ and $76.5 \pm 3.4 \mu \mathrm{M}$, respectively. Water temperature and electrical conductivity were measured by an YSI multiple probe (Pro 1030, YSI, Yellow Springs, OH, USA).

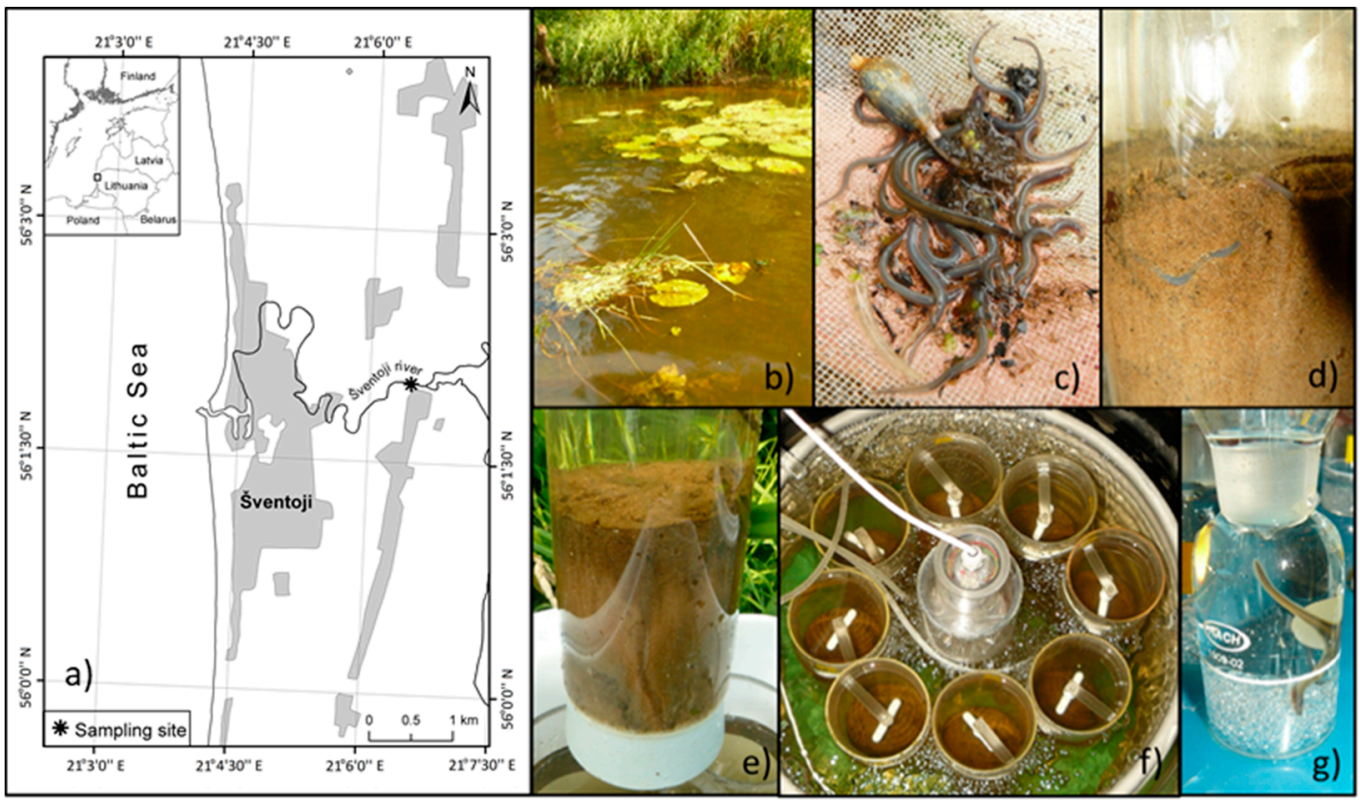

Figure 1. The figure depicts the location of the sampling site, indicated with the asterisk (a), a detail of the river course with floating-leaved vegetation (b), Lampetra sp. larvae retrieved from sieved sediment (c), a burrowed ammocoete (d), an intact sediment core (e), a sediment cores incubation tank with stirring units and temperature control system (f) and a bottle with glass beads used for ammocoetes individual incubation $(\mathbf{g})$.

Lampreys are of conservation concern in Europe and are listed on Annex II of the European Union Habitats Directive (92/43/EEC) and collection of any Lampetra sp. ammocoete is prohibited. Sampling of lamprey larvae for our study was carried out with a special fishing permit, in the framework of a fish communities sampling program. Ammocoetes 
were collected from shallow marginal areas without vegetation (depth $0.2-0.3 \mathrm{~m}$, low to undetectable water velocity) from muddy sand oxidized sediments. To this purpose, surface sediment layers (0-10 cm depth) were collected with squared plastic frames exploring areas of $300 \mathrm{~cm}^{2}$ and sieved with $1 \mathrm{~mm}$ sieve in order to retrieve larvae. Alive lamprey larvae were transferred into buckets filled with river water. In addition, 32 intact sediment cores (i.d. $8 \mathrm{~cm}$, length $30 \mathrm{~cm}$ ) were collected by hand from the adjacent undisturbed area in order to have nearly $10 \mathrm{~cm}$ of sediments and $20 \mathrm{~cm}$ of clear water phase. Three smaller intact cores (i.d. $3.5 \mathrm{~cm}$, length $25 \mathrm{~cm}$ ) were collected for general characterization of sediment and $200 \mathrm{~L}$ of in situ river water was collected for ammocoetes bioturbated sediment preincubation and incubation procedures.

\subsection{Measurement of Ammocoetes Respiration and Excretion Rates}

Single ammocoetes collected from the river were selected according to their body size in order to cover a wide range of lengths (from 4 to $10 \mathrm{~cm}, n=25$ ). In the laboratory, they were gently transferred to $100 \mathrm{~mL}$ BOD (biological oxygen demand) glass vials containing sterilized glass beads to reproduce a sedimentary environment and $0.22 \mu \mathrm{m}$-filtered river water. Vials with ammocoetes were incubated in the dark at in situ temperature $\left(18{ }^{\circ} \mathrm{C}\right)$ (Figure 1g). At the beginning and at the end of the incubation $\sim 60 \mathrm{~mL}$ of water was collected with plastic syringes from the incubation tank $\left(t_{0}\right)$ and from the bottles $\left(t_{f}\right)$. Initial and final water samples were dispensed and treated for different purposes. An aliquot of $30 \mathrm{~mL}$ was transferred to 12-mL Exetainer (Labco Scientific, Lampeter, UK) flushing the volume twice for dissolved $\mathrm{O}_{2}$ analysis and immediately preserved with $50 \mu \mathrm{L}$ of $4 \%$ $\mathrm{HgCl}_{2}$. Another aliquot of $30 \mathrm{~mL}$ was filtered (GF/F filters) and transferred to scintillation vials for inorganic nutrient analyses $\left(\mathrm{NH}_{4}{ }^{+}, \mathrm{NO}_{3}{ }^{-}, \mathrm{PO}_{4}{ }^{3-}\right.$ and $\left.\mathrm{SiO}_{2}\right)$. Dissolved inorganic nutrients were measured within $12 \mathrm{~h}$ (see Section 2.4). Incubations lasted from 0.5 to $1.5 \mathrm{~h}$ in order to keep final $\mathrm{O}_{2}$ concentrations within $30 \%$ of the initial value. At the end of the incubations, test animals were euthanized overdosing anesthetic 2-phenoxyethnol, their length was measured and the dry weight (DW) of each ammocoete was measured after drying at $60{ }^{\circ} \mathrm{C}$ to a constant weight. Biomass specific ammocoetes respiration and excretion rates ( $\mu \mathrm{mol} \mathrm{g}_{\mathrm{DW}}{ }^{-1} \mathrm{~h}^{-1}$ ) were calculated according to Equation (1):

$$
\text { Flux }=\frac{\left[\left(C_{f}-C_{i}\right) \times V\right]}{t \times B},
$$

where $C_{f}$ and $C_{i}$ are the final and initial concentrations of the target solute $(\mu \mathrm{M}), V$ is the volume of the BOD glass vials corrected for the volume of glass beads $(\mathrm{L}), t$ is the incubation time $(\mathrm{h})$ and $B$ is the ammocoetes biomass $\left(\mathrm{g}_{\mathrm{DW}}\right)$.

\subsection{Measurements of Benthic Fluxes in Lamprey Larvae Bioturbated Sediments}

In the laboratory, all cores were maintained at the same temperature of the natural environment $\left(18^{\circ} \mathrm{C}\right)$ submerged with the top open in temperature-controlled incubation tanks containing aerated river water (Figure 1f). Then, variable numbers of ammocoetes were added to the cores (from 0 to a maximum of 4 individuals per core) in order to study the effect of their biomass on benthic processes. Once added, all lampreys were rapidly digging in surface sediments, creating with their body U-shaped burrows, with head and tail at the sediment-water interface and the body entirely hidden within the sediments. Thereafter sediments with lampreys were pre-incubated overnight in the tanks. The day after, dissolved $\mathrm{O}_{2}$ and inorganic nutrient fluxes were measured in the dark according to a start-end standard incubation procedure [32]. Before starting the incubation, the water in the tanks was renewed with fresh in situ water. At the beginning of the measurements, water samples (ca. $100 \mathrm{~mL}, n=5, t_{0}$ ) were collected from each tank with plastic syringes and all cores were closed with rubber stoppers. An incubation period of $4-5 \mathrm{~h}$ was set in order to keep the final $\mathrm{O}_{2}$ concentration within $20-30 \%$ of the initial value. At the end of the incubation, a water sample (ca. $100 \mathrm{~mL}, t_{f}$ ) was collected from each core. All samples were 
processed as described in Section 2.2. Net fluxes of all measured solutes $\left(\mu \mathrm{mol} \mathrm{m}{ }^{-2} \mathrm{~h}^{-1}\right)$ across the sediment-water interface were calculated according to Equation (2):

$$
\text { Flux }=\frac{\left[\left(C_{f}-C_{i}\right) \times V\right]}{t \times A},
$$

where $C_{f}$ and $C_{i}$ are the final and initial concentrations of the target solute $(\mu \mathrm{M}), V$ is the volume of the water phase in the core $(\mathrm{L}), t$ is the incubation time $(\mathrm{h})$ and $A$ is the sediment surface in the core $\left(\mathrm{m}^{2}\right)$.

\subsection{Sediment Characterization and Analytical Methods for Water Samples}

Three small sediment cores were extruded and sliced for chlorophyll $a$, organic matter and grain size analysis. Sediment chlorophyll $a$ was measured spectrophotometrically in the upper $0.5 \mathrm{~cm}$ sediment layer according to [33], after $24 \mathrm{~h}$ extraction in $90 \%$ acetone. Organic carbon $\left(\mathrm{C}_{\text {org }}\right)$ was analyzed in dried sediments from the upper 0-2 cm layer with a Shimadzu total organic carbon (TOC) analyzer (Tokyo, Japan) equipped with a compartment for solid analysis. An aliquot of wet sediment was employed for sediment grain size analysis with a laser particle size analyzer (Analysette 22 MicroTec plus, Fritsch $\mathrm{GmbH}$, Idar-Oberstein, Germany).

Dissolved $\mathrm{O}_{2}$ concentration was measured with a microelectrode (OX-50, Unisense A/S, Aarhus, Denmark). Dissolved inorganic nutrients $\left(\mathrm{NO}_{3}{ }^{-}, \mathrm{PO}_{4}{ }^{3-}\right.$ and $\mathrm{SiO}_{2}$ ) were measured with a continuous flow analyzer (San++, Skalar Analytical B.V., Breda, The Netherlands) using standard colorimetric methods [34]. Ammonium was analyzed manually by means of the salicylate-hypochlorite method, using nitroprussiate as a catalyst [35].

\subsection{Statistical Analysis}

Data on respiration and nutrient excretion were plotted against ammocoetes dry biomass and logarithmic regression curves were fitted where appropriate. Data on benthic respiration and nutrient fluxes were plotted against ammocoetes dry weight and analyzed via linear regression. The coefficient of determination and statistical significance are provided for the regression models. Significance level for all tests was $p<0.05$. All statistical analyses were performed via Sigma Plot 12.0 (Systat Software Inc., San Jose, CA, USA).

\section{Results and Discussion}

\subsection{Sampling Site Features}

Large portions of the Šventoji River marginal areas were covered by fine sand deposits $(\mathrm{Md}=0.195 \pm 0.012 \mathrm{~mm})$, in which the silt fraction $(<63 \mu \mathrm{m})$ contributed a small percentage of the total $(16.6 \pm 3.9 \%$ on average). The studied sediments are typical for most of Lithuanian lowland rivers marginal habitats occupied by lamprey larvae. In a prior study on habitat selection, lamprey larvae were demonstrated to be habitat specialists that prefer fine-sand sediments, and to a lesser extent organic-rich bottom environments $[24,36]$. Such selection is likely driven by much lower microbial activity and $\mathrm{O}_{2}$ consumption in organicpoor sediments. Lotic ecosystems generally do not display $\mathrm{O}_{2}$ shortage due to water flow, however shallow areas with low current velocity are sites of fine sediments accumulation where $\mathrm{O}_{2}$ demand and supply can be decoupled, resulting in local undersaturation. Another important aspect related to habitat selection by lamprey larvae is the build-up of anaerobic metabolism end-products (e.g., $\mathrm{NH}_{4}{ }^{+}$, chemically reduced metals, sulphides) in sediments receiving elevated inputs of labile organic matter. These end-products may accumulate in pore water, and be toxic to ammocoetes. The sediments of Šventoji River marginal areas, where ammocoetes were collected, appeared light brown and quite oxidized along the upper 10-20 cm horizon, without vertical redox discontinuities (Figure 1e). Sediment oxidation may derive by low heterotrophic microbial activity at the study site. The latter is due to low organic matter content in sediments (Corg $=0.6 \pm 0.2 \%$ of the sediment dry weight) and to the presence of coarse fragments of leaves from terrestrial 
origin, that are generally refractory to mineralization due to their high cellulosic content. Such oxidation can also be a direct consequence of elevated bioturbation by lamprey larvae, favoring the oxidation of reduced chemical forms [19]. Experimental studies on ammocoetes behavior in reconstructed sediments demonstrated a high mobility of larvae within the upper $4-5 \mathrm{~cm}$ sediment horizon during the day and during the night, resulting in elevated bioturbation-induced oxidation and increased sediment redox [19,37]. Such experiments revealed that ammocoetes move inside the substrate without leaving it and that surface activity was observed rarely.

When ammocoetes dig within sediments they stabilize the fine sand particles of burrow walls by producing mucus, as demonstrated for other macrofauna groups [38]. Fine sediments are a specific requirement for ammocoetes as larger particles are more difficult to penetrate by larvae or to solidify with mucus and would result in burrow collapse. This may explain the large densities of ammocoetes at the study site, whereas elsewhere lampreys are declining in numbers due to specific habitat loss (e.g., increase of sedimentation and organic content) [31]. At the study site, water transparency and shallowness favored the growth of microphytobenthos and surface sediments displayed

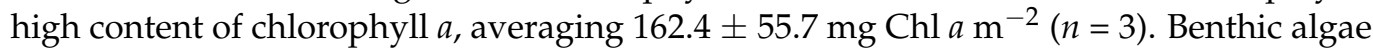
represent high quality organic matter at the sediment surface, and may constitute a food source for ammocoetes [39]. Nutrient concentrations in the Šventoji River water were low, and typical of the dry season and of lowland streams within forested catchments.

\subsection{Size, Weight and Metabolic Activity of the Ammocoetes Retrieved in the Šventoji River}

In the Šventoji River, lamprey larvae represent Lampetra genus and could belong to both river (L. fluviatilis) and brook lamprey (L. planeri); however, the area is mostly used for river lamprey spawning and rearing habitat. It is very difficult to distinguish the two species during their larval stage due to rather similar morphology [31]; moreover, there are no clear differences between brook and river lamprey ammocoetes sediment preference, burrowing and feeding behavior. Sampled river-marginal area hosted a Lampetra sp. population including all size classes (from $0+$ sub-yearlings to 5 year old larvae). The length of larvae retrieved from sediments $(n=114)$ varied between 11 and $105 \mathrm{~mm}$ (average $47 \pm 16 \mathrm{~mm}$ ), corresponding to a dry weight between 0.002 and $0.305 \mathrm{~g}_{\mathrm{DW}}$ ind $^{-1}$ (average $0.046 \pm 0.053 \mathrm{~g}_{\mathrm{DW}}$ ind $^{-1}$ ). However, the distribution of frequencies of body length (not shown) suggests that individuals with length between 40 and $60 \mathrm{~mm}$ represented nearly $50 \%$ of the retrieved animals, and animals with a size within that range were used in the sediment core incubations.

Lamprey larvae alone incubations revealed large differences, generally by one order of magnitude, of the biomass-normalized metabolic and excretion rates (Figure 2). Smaller individuals displayed higher metabolic and excretion activities than larger individuals, as reported in analogous studies on invertebrate macrofauna (e.g., the filter-feeding bivalves Dreissena polymorpha or Sinanodonta woodiana) [32,40]. Oxygen respiration rates varied between 20 and $200 \mu \mathrm{mol} \mathrm{O} \mathrm{g}_{\mathrm{DW}}{ }^{-1} \mathrm{~h}^{-1}$ (Figure 2a). Ammocoetes displayed lower metabolic activity and lower excretion rates when compared to teleosts of similar size, likely due to the environment where they spend most of their time (i.e., the sediment, which is a hostile environment for $\mathrm{O}_{2}$ exigent organisms) [41]. However, ammocoetes respiration rates aligned with ranges reported for other bioturbators (e.g., 10-260 $\mu \mathrm{mol}$ $\mathrm{O}_{2} \mathrm{~g}_{\mathrm{DW}}{ }^{-1} \mathrm{~h}^{-1}$ for different bivalves and $90-140 \mu \mathrm{mol} \mathrm{O}_{2} \mathrm{~g}_{\mathrm{DW}}{ }^{-1} \mathrm{~h}^{-1}$ for burrowing chironomid larvae) [40,42]. Rates of $\mathrm{NH}_{4}{ }^{+}$excretion $\left(\sim 2\right.$ to $\left.\sim 13 \mu \mathrm{mol} \mathrm{NH}{ }_{4}^{+} \mathrm{gDW}^{-1} \mathrm{~h}^{-1}\right)$ were one order of magnitude lower than the absolute values of $\mathrm{O}_{2}$ consumption but displayed a similar trend with much higher excretion measured in smaller organisms (Figure $2 b$ ). Similar results are reported also in [32,40]. Ammocoetes mostly released $\mathrm{NH}_{4}{ }^{+}$to the water but different authors report that up to $15-20 \%$ of excreted $\mathrm{N}$ is in the form of urea, not quantified in the present study [43]. During larvae alone incubations, net accumulation of $\mathrm{NO}_{3}{ }^{-}$in the water was also measured (Figure 2c). However, ammocoetes-related $\mathrm{NO}_{3}{ }^{-}$ fluxes were generally lower than $2 \mu \mathrm{mol} \mathrm{NO}{ }_{3}^{-} \mathrm{gDW}^{-1} \mathrm{~h}^{-1}$, and did not exhibit a clear 
size-dependent trend. Such $\mathrm{NO}_{3}{ }^{-}$could be produced via nitrification by bacteria colonizing the skin of ammocoetes, oxidizing part of the excreted $\mathrm{NH}_{4}{ }^{+}$, as reported for other burrowing organisms [44]. The absolute value of the molar ratio between $\mathrm{O}_{2}$ and $\mathrm{NH}_{4}{ }^{+}$ fluxes measured in incubations of individual ammocoetes averaged $17.1 \pm 4.1$, whereas the $\mathrm{O}_{2}$ to $\mathrm{NH}_{4}{ }^{+}+\mathrm{NO}_{3}{ }^{-}$molar ratio averaged $13.8 \pm 2.9$. Such ratios, that do not consider urea excretion, can be considered as proxies of the C:N ratio of the ammocoetes food particles and suggest high quality, N-rich organic matter as phytoplankton, microphytobenthos or labile organic detritus as food source [39]. Excreted phosphorus is generally associated with feces, but high fluxes of $\mathrm{PO}_{4}{ }^{3-}$ from ammocoetes were also measured (0.4 to $2.4 \mu \mathrm{mol}$ $\mathrm{PO}_{4}{ }^{3-} \mathrm{g}_{\mathrm{DW}}{ }^{-1} \mathrm{~h}^{-1}$ ) (Figure 2d). To our knowledge, this is the first time that $\mathrm{PO}_{4}{ }^{3-}$ excretion was reported for ammocoetes, as most studies considered only $\mathrm{N}$ compounds. The molar ratio between $\mathrm{NH}_{4}{ }^{+}$and $\mathrm{PO}_{4}{ }^{3-}$ release was surprisingly low and averaged 8.2 \pm 3.7 . This may suggest that part of the ammocoetes excreted N, rather than $\mathrm{P}$, is associated to biodeposits. Ammocoetes alone incubations revealed also variable release of $\mathrm{SiO}_{2}$, from $<1$ to $25 \mu \mathrm{mol} \mathrm{SiO} 2 \mathrm{gDW}^{-1} \mathrm{~h}^{-1}$ (Figure 2e). Such release falls within the range reported for filter-feeding bivalves [32,40]. In some of the incubated ammocoetes, the $\mathrm{NH}_{4}{ }^{+}$to $\mathrm{SiO}_{2}$ excretion ratio was close to unity. Silica excretion supports studies reporting diatoms as a food source of ammocoetes [39]. Reactive $\mathrm{P}$ and $\mathrm{SiO}_{2}$ excretion displayed a tendency towards higher rates in smaller organisms, as shown for $\mathrm{O}_{2}$ and $\mathrm{NH}_{4}{ }^{+}$, but with a larger degree of variability.

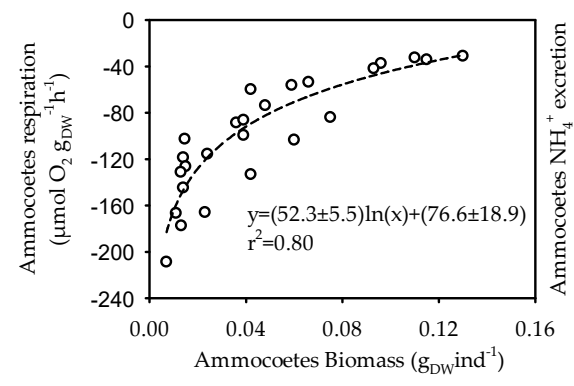

(a)

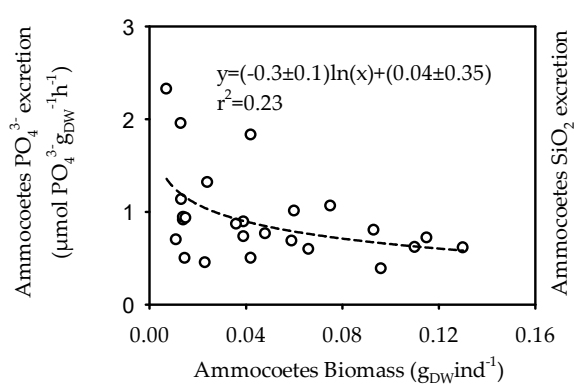

(d)

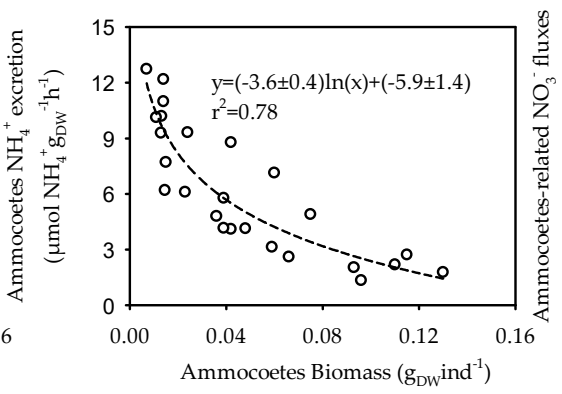

(b)

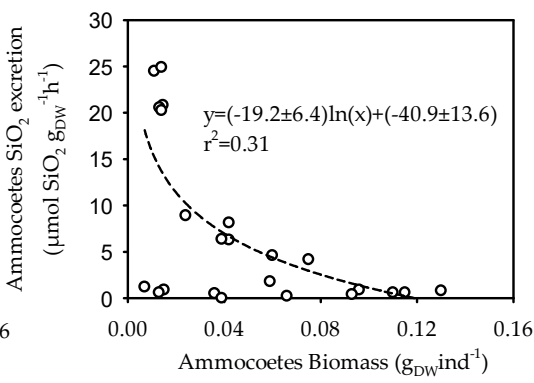

(e)

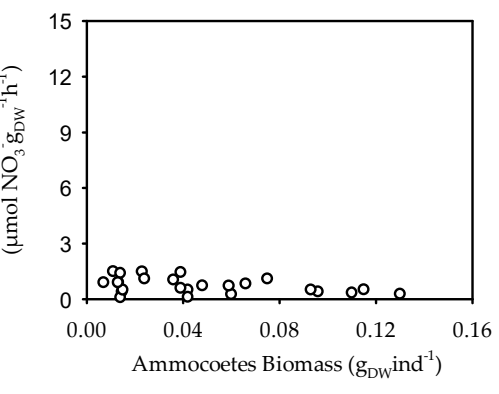

(c)

Figure 2. Biomass-normalized rates of oxygen respiration (a), nutrient excretion $(\mathbf{b}, \mathbf{d}, \mathbf{e})$ by ammocoetes and $\mathrm{NO}_{3}{ }^{-}$ production (c) plotted as a function of their individual biomass. All rates were determined via incubations of ammocoetes of variable size $(n=25)$ in $100 \mathrm{~mL}$ glass bottles provided with an artificial substrate (glass beads).

\subsection{Benthic Respiration and Nutrient Fluxes in Sediments Bioturbated by Ammocoetes}

Lamprey density in incubated cores varied between 0 and 600 ind $\mathrm{m}^{-2}$ and the average larvae biomass added to sediments was $0.028 \pm 0.008 \mathrm{~g}_{\mathrm{DW}}$. Through their respiration and burrowing activity, lampreys enhanced benthic $\mathrm{O}_{2}$ and $\mathrm{NO}_{3}{ }^{-}$consumption and $\mathrm{NH}_{4}{ }^{+}$ excretion (Figure $3 \mathrm{a}-\mathrm{c}$ ), whereas $\mathrm{PO}_{4}{ }^{3-}$ and $\mathrm{SiO}_{2}$ fluxes tended to increase, but slopes were not significantly different from zero (Figure $3 \mathrm{~d}, \mathrm{e})$. 


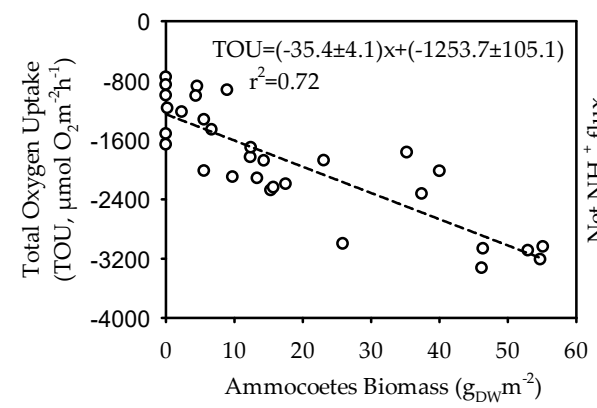

(a)

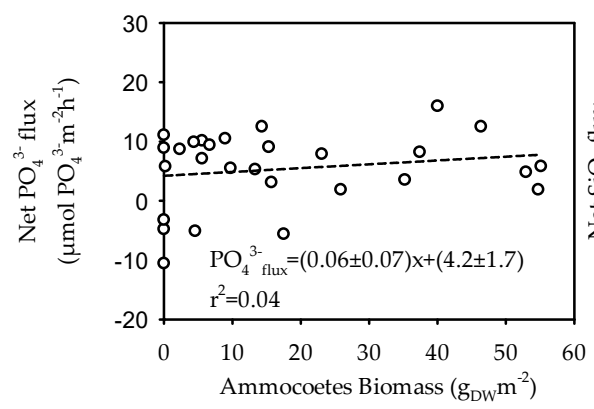

(d)

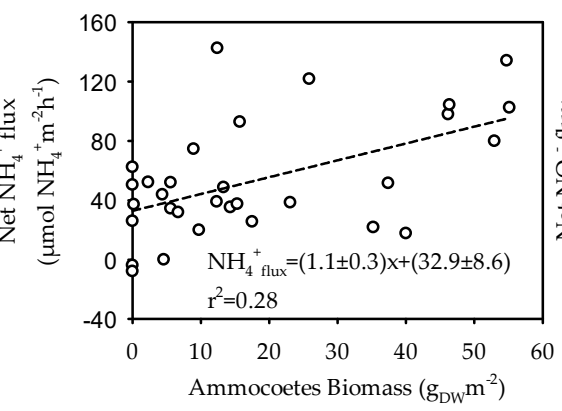

(b)

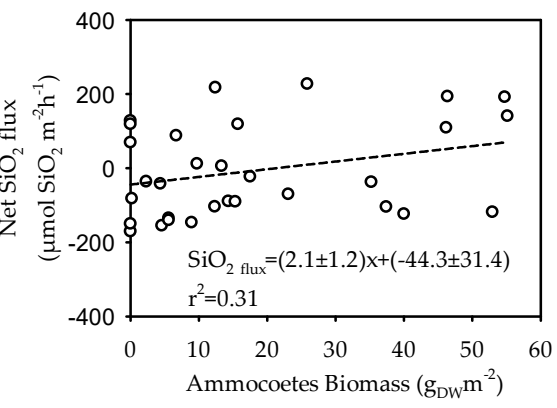

(e)

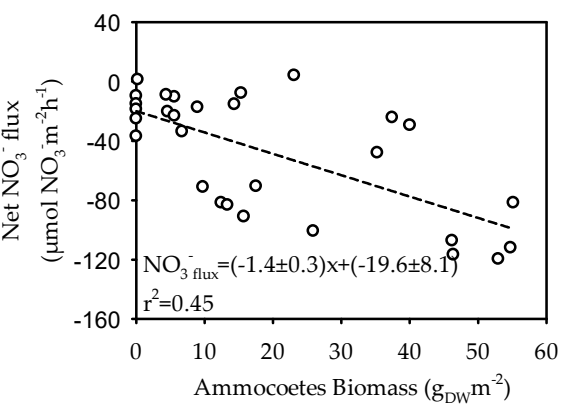

(c)

Figure 3. Total oxygen uptake (a) and net nutrient fluxes (b-e) measured in sediments with different biomass of ammocoetes $(n=32)$. Graphs report also the linear regressions between process rates and ammocoetes biomass. Slopes were significant for total oxygen uptake (TOU) $(p<0.0001), \mathrm{NH}_{4}{ }^{+}(p=0.002), \mathrm{NO}_{3}{ }^{-}(p<0.0001), \mathrm{PO}_{4}{ }^{3-}(p=0.340)$ and $\mathrm{SiO}_{2}(p=0.100)$ fluxes.

Similar stimulation of total $\mathrm{O}_{2}$ uptake in sediments with ammocoetes was demonstrated in macrofauna bioturbation studies $[6,8,14,40]$. Burrowing organisms increase benthic $\mathrm{O}_{2}$ consumption due to their metabolic activity and to the subsurface burrow structures, that expand the surface through which dissolved $\mathrm{O}_{2}$ can diffuse. Ammocoetes do not construct deep burrows and it is likely that most of the increase of benthic $\mathrm{O}_{2}$ demand is due to the ammocoetes respiration. What is known is that ammocoetes frequently change their position within sediments, so they dig frequently, but it is not clear whether they perform a ventilation of their burrows. From visual observations this is unlikely, as they feed directly from the water, taking advantage of continuous water renewal in lotic ecosystems. At $18^{\circ} \mathrm{C}$ the respiration of bare sediments (without ammocoetes) was $1253 \mu \mathrm{mol}$ $\mathrm{O}_{2} \mathrm{~m}^{-2} \mathrm{~h}^{-1}$, which is expected for sandy sediments with low organic matter content as at the study site and as reported in similar substrates [8]. Such respiration increased by $\sim 35 \mu \mathrm{mol} \mathrm{O} \mathrm{O}_{2} \mathrm{~m}^{-2} \mathrm{~h}^{-1}$ per gram dry weight of ammocoetes (Figure 3a). Such value falls within the range of biomass-normalized ammocoetes respiration rates, and suggests that most of the increase of benthic $\mathrm{O}_{2}$ consumption in sediments with ammocoetes was due to the larvae respiratory needs. In a similar experiment, the addition of the oligochaete Sparganophilus tamesis to muddy and sandy sediment determined an increase of 26 and $17 \mu \mathrm{mol} \mathrm{O} \mathrm{m}^{-2} \mathrm{gDW}_{\mathrm{DW}}{ }^{-1} \mathrm{~h}^{-1}$ whereas large individuals of $S$. woodiana stimulated $\mathrm{O}_{2}$ demand by less than $10 \mu \mathrm{mol} \mathrm{O} \mathrm{m}^{-2} \mathrm{~g}_{\mathrm{DW}}{ }^{-1} \mathrm{~h}^{-1}[8,40]$. Single individual incubations revealed large $\mathrm{NH}_{4}{ }^{+}$excretion, which was substantially reduced when ammocoetes were in sediments, likely due to benthic assimilation (by bacteria or microphytobenthos) or nitrification in the aerobic sediment volume. Increasing ammocoetes biomass resulted in more negative $\mathrm{NO}_{3}{ }^{-}$ fluxes, supporting what is generally found with burrowing organisms via isotope-based techniques: an increase of denitrification rates [6]. Similarly, high rates of P and Si excretion did not result in increased fluxes in lamprey larvae bioturbated sediment incubations, likely due to coupled retention (e.g., via dark assimilation or co-precipitation) of these nutrients in the sandy sediments of the Šventoji River. Overall, the combination of ammocoetes alone and bioturbated sediment incubations suggest that lamprey larvae retain high quality particles via ingestion and recycle large quantities of nutrients that do not accumulate in 
the water column but are likely reused within sediment by microbial community or on the sediment surface by microphytobenthos.

\section{Conclusions}

Taken together, results from this experimental study support previous findings that lamprey larvae are ecosystem engineers capable via their own metabolism and burrowing activities to affect sediments physical, chemical and biological features. The impact of an ecosystem engineer on the environment is a function of three main biological aspects: its behavior, body size, and population density, all mediated by the abiotic conditions [4]. Following this concept, Lampetra ammocoetes seem to be influential bioturbators, because: (a) they are vigorous burrowers, actively bioturbating and displacing sediments; (b) lamprey community consists of several year cohorts, with the biggest individuals up to 7-10 cm; and (c) the density in a healthy system could reach high numbers, as in Šventoji River case, and as tested in our experimental setup. Larval densities have been determined by a number of researchers and found to be very variable, both from place to place and from year to year in the same place [31]. In some Lithuanian rivers, proposed as NATURA 2000 sites for lampreys, Lampetra sp. density ranged from a few ind. $\mathrm{m}^{-2}$ in large rivers to density up to 46 ind $\mathrm{m}^{-2}$ in Šventoji River [45].

We demonstrated the important role of lamprey larvae as regulators of nutrient cycling in riverine systems, coupling pelagic production with the benthic compartment and taking an active role in nutrient spiraling. This role is comparable to that of filter-feeding mollusks, that in pristine lotic ecosystems, via filtration and excretion, were promoting the recycling of otherwise limiting nutrients. Besides excreting all the key nutrients and enriching sediments with biodeposits, lamprey larvae actively bioturbated sediments, improving their chemical quality (e.g., increasing $\mathrm{O}_{2}$ and $\mathrm{NO}_{3}{ }^{-}$penetration and pore water redox potential), augmenting the communities of aerobic bacteria and mixing refractory and labile particles, producing a stimulatory effect on organic matter microbial mineralization. As such, ammocoetes act as burrowing macrofauna, even if they do not assume a static feeding position in the substrate. Contrarily to burrowing fauna, ammocoetes do not consolidate and ventilate their burrows creating biogeochemical hotspots, rather they seem to produce a much more diffuse effect on surface sediments. Incubation of single ammocoetes revealed elevated excretion of inorganic N, Si and P, but such fluxes were attenuated when ammocoetes were burrowed. Frequent movements of ammocoetes in sediments result in particles reworking and in multiple injections of oxic or nitrate-rich water in sediments, potentially affecting pore water chemistry and microbial community composition. Such movements might also favor the retention of excreted nutrients in microbial biomass within nutrient-poor sandy sediments. Ammocoetes might therefore increase the nutritional quality of sediments, with cascade implications for different trophic levels, likely sustaining the heterotrophic microbial communities, benthic primary producers, meio- and macrofauna $[5,46]$. Even more, ammocoetes tend to drift downstream with their aging [21,31], displacing the biogeochemical services they provide from upstream spawning sections to downstream reaches with low or no local ammocoetes recruitment.

Further investigations, combining molecular and biogeochemical techniques may reveal hidden and interactive associations between ammocoetes and microbial community, which are important for the functioning of lotic ecosystems. Such investigations should also expand the sediment typologies of marginal areas where ammocoetes burrow to allow generalization of the presented results.

Author Contributions: Conceptualization, N.N.; methodology, M.Z., T.R., G.G., K.B., S.B. and M.B.; validation, N.N., M.B. and S.B.; investigation, M.Z., T.R., G.G., K.B.; data curation, N.N.; writingoriginal draft preparation, N.N.; writing-review and editing, all co-authors.; funding acquisition, N.N., M.Z. All authors have read and agreed to the published version of the manuscript.

Funding: This research received no external funding. 
Institutional Review Board Statement: Ethical review and approval were waived for this study, that was performed in the framework of a larger scale monitoring of fish communities in Lithuanian waters previously approved by Environmental Protection Agency with special fishing permit.

Informed Consent Statement: Not applicable.

Data Availability Statement: Data can be accessed upon request to the corresponding author.

Acknowledgments: We are grateful to Irma Vybernaitė-Lubienė, Jolita Petkuvienè and Jovita Mèžinė for their help with laboratory analyses of water and sediment samples.

Conflicts of Interest: The authors declare no conflict of interest.

\section{References}

1. Kristensen, E. Organic matter diagenesis at the oxic/anoxic interface in coastal marine sediments, with emphasis on the role of burrowing animals. In Life at Interfaces and under Extreme Conditions; Liebezeit, G., Dittmann, S., Kröncke, I., Eds.; Springer: Dordrecht, The Netherlands, 2000; pp. 1-24, ISBN 978-94-010-5808-7.

2. Kristensen, E.; Penha-Lopes, G.; Delefosse, M.; Valdemarsen, T.; Quintana, C.; Banta, G. What Is Bioturbation? The Need for a Precise Definition for Fauna in Aquatic Sciences. Mar. Ecol. Prog. Ser. 2012, 446, 285-302. [CrossRef]

3. Adámek, Z.; Maršáalek, B. Bioturbation of Sediments by Benthic Macroinvertebrates and Fish and Its Implication for Pond Ecosystems: A Review. Aquacult. Int. 2013, 1-17. [CrossRef]

4. Moore, J.W. Animal Ecosystem Engineers in Streams. BioScience 2006, 56, 237-246. [CrossRef]

5. Boeker, C.; Lueders, T.; Mueller, M.; Pander, J.; Geist, J. Alteration of Physico-Chemical and Microbial Properties in Freshwater Substrates by Burrowing Invertebrates. Limnologica 2016, 59, 131-139. [CrossRef]

6. Pelegrí, S.P.; Blackburn, T.H. Effect of Bioturbation by Nereis Sp., Mya Arenaria and Cerastoderma Sp. on Nitrification and Denitrification in Estuarine Sediments. Ophelia 1995, 42, 289-299. [CrossRef]

7. Nielsen, O.; Gribsholt, B.; Kristensen, E.; Revsbech, N. Microscale Distribution of Oxygen and Nitrate in Sediment Inhabited by Nereis Diversicolor: Spatial Patterns and Estimated Reaction Rates. Aquat. Microb. Ecol. 2004, 34, 23-32. [CrossRef]

8. Benelli, S.; Bartoli, M.; Ribaudo, C.; Fano, E. Contrasting Effects of an Alien Worm on Benthic N Cycling in Muddy and Sandy Sediments. Water 2019, 11, 465. [CrossRef]

9. Bartoli, M.; Benelli, S.; Magri, M.; Ribaudo, C.; Moraes, P.C.; Castaldelli, G. Contrasting Effects of Bioturbation Studied in Intact and Reconstructed Estuarine Sediments. Water 2020, 12, 3125. [CrossRef]

10. Nascimento, F.J.A.; Näslund, J.; Elmgren, R. Meiofauna Enhances Organic Matter Mineralization in Soft Sediment Ecosystems. Limnol. Oceanogr. 2012, 57, 338-346. [CrossRef]

11. Bonaglia, S.; Nascimento, F.J.A.; Bartoli, M.; Klawonn, I.; Brüchert, V. Meiofauna Increases Bacterial Denitrification in Marine Sediments. Nat. Commun. 2014, 5, 5133. [CrossRef]

12. Rosenberg, R. Marine Benthic Faunal Successional Stages and Related Sedimentary Activity. Sci. Mar. 2001, 65, 107-119. [CrossRef]

13. Kristensen, E.; Delefosse, M.; Quintana, C.O.; Flindt, M.R.; Valdemarsen, T. Influence of Benthic Macrofauna Community Shifts on Ecosystem Functioning in Shallow Estuaries. Front. Mar. Sci. 2014, 1, 41. [CrossRef]

14. Benelli, S.; Bartoli, M.; Zilius, M.; Vybernaite-Lubiene, I.; Ruginis, T.; Vaiciute, D.; Petkuviene, J.; Fano, E.A. Stoichiometry of Regenerated Nutrients Differs between Native and Invasive Freshwater Mussels with Implications for Algal Growth. Freshw. Biol. 2019, 64, 619-631. [CrossRef]

15. Breukelaar, A.W.; Lammens, E.H.R.R.; Breteler, J.G.P.K.; Tatrai, I. Effects of Benthivorous Bream (Abramis Brama) and Carp (Cyprinus Carpio) on Sediment Resuspension and Concentrations of Nutrients and Chlorophyll a. Freshw. Biol. 1994, 32, 113-121. [CrossRef]

16. Hogg, R.S.; Coghlan, S.M.; Zydlewski, J.; Simon, K.S. Anadromous Sea Lampreys (Petromyzon Marinus) Are Ecosystem Engineers in a Spawning Tributary. Freshw. Biol. 2014, 59, 1294-1307. [CrossRef]

17. Gottesfeld, A.S.; Hassan, M.A.; Tunnicliffe, J.F. Salmon Bioturbation and Stream Process. Am. Fish. Soc. Symp. 2008, 65, 175-193.

18. Nika, N.; Virbickas, T. Brown Trout Salmo Trutta Redd Superimposition by Spawning Lampetra Species in a Lowland Stream. J. Fish Biol. 2010, 77, 2358-2372. [CrossRef]

19. Boeker, C.; Geist, J. Lampreys as Ecosystem Engineers: Burrows of Eudontomyzon sp. and Their Impact on Physical, Chemical, and Microbial Properties in Freshwater Substrates. Hydrobiologia 2016, 777, 171-181. [CrossRef]

20. Shirakawa, H.; Yanai, S.; Goto, A. Lamprey Larvae as Ecosystem Engineers: Physical and Geochemical Impact on the Streambed by Their Burrowing Behavior. Hydrobiologia 2013, 701, 313-322. [CrossRef]

21. Potter, I.C. Ecology of Larval and Metamorphosing Lampreys. Can. J. Fish. Aquat. Sci. 1980, 37, 1641-1657. [CrossRef]

22. Hardisty, M.W.; Potter, I.C. The Behaviour, Ecology and Growth of Larval Lampreys. In The Biology of Lampreys; Hardisty, M.W., Potter, I.C., Eds.; Academic Press: London, UK, 1971; pp. 85-125.

23. Smith, D.M.; Welsh, S.A.; Turk, P.J. Available Benthic Habitat Type May Influence Predation Risk in Larval Lampreys: Predation Risk in Larval Lampreys. Ecol. Freshw. Fish 2012, 21, 160-163. [CrossRef] 
24. Aronsuu, K.; Virkkala, P. Substrate Selection by Subyearling European River Lampreys (Lampetra Fluviatilis) and Older Larvae (Lampetra spp). Ecol. Freshw. Fish 2014, 23, 644-655. [CrossRef]

25. Ojutkangas, E.; Aronen, K.; Laukkanen, E. Distribution and Abundance of River Lamprey (Lampetra fluviatilis) Ammocoetes in the Regulated River Perhonjoki. Regul. Rivers Res. Mgmt. 1995, 10, 239-245. [CrossRef]

26. Enequist, P. Das Bachneunauge Als Ökologische Modification Des Flussneunauges. Über Die Fluss- Und Bachneunaugen Schwedens. Ark. Für Zool. 1937, 29, 1-22.

27. Hardisty, M.W. The Life History and Growth of the Brook Lamprey (Lampetra planeri). J. Anim. Ecol. 1944, 13, 110-122. [CrossRef]

28. Hardisty, M.W. Biology of the Cyclostomes; Chapman \& Hall: London, UK, 1979.

29. Vaughn, C.C. Biodiversity Losses and Ecosystem Function in Freshwaters: Emerging Conclusions and Research Directions. BioScience 2010, 60, 25-35. [CrossRef]

30. Renaud, C.B. Conservation Status of Northern Hemisphere Lampreys (Petromyzontidae). J. Appl. Ichthyol. 1997, 13, 143-148. [CrossRef]

31. Maitland, P.S. Ecology of the River, Brook and Sea Lamprey. In Conserving Natura 2000 Rivers Monitoring; English Nature: Peterborough, UK, 2003; p. 52.

32. Ruginis, T.; Bartoli, M.; Petkuviene, J.; Zilius, M.; Lubiene, I.; Laini, A.; Razinkovas-Baziukas, A. Benthic Respiration and Stoichiometry of Regenerated Nutrients in Lake Sediments with Dreissena polymorpha. Aquat. Sci. 2014, 76, 405-417. [CrossRef]

33. Lorenzen, C.J. Determination of Chlorophyll and Pheo-pigments: Spectrophotometric Equations. Limnol. Oceanogr. 1967, 12, 343-346. [CrossRef]

34. Grasshoff, K.; Ehrhardt, M.; Kremling, K. Methods of Seawater Analysis, 2nd ed.; Verlag Chemie: Berlin, Germany, 1983.

35. Bower, C.E.; Holm-Hansen, T. A Salicylate-Hypochlorite Method for Determining Ammonia in Seawater. Can. J. Fish. Aquat. Sci. 1980, 37, 794-798. [CrossRef]

36. Smith, D.M.; Welsh, S.A.; Turk, P.J. Selection and Preference of Benthic Habitat by Small and Large Ammocoetes of the Least Brook Lamprey (Lampetra aepyptera). Environ. Biol. Fish 2011, 91, 421-428. [CrossRef]

37. Moser, M.; Bayer, J.; MacKinlay, D. The Biology of Lampreys-Symposium Proceedings. In Proceedings of the International Congress on the Biology of Fish University of British Columbia, Vancouver, BC, Canada, 22-25 July 2002.

38. Wotton, R.S. The Ubiquity and Many Roles of Exopolymers (EPS) in Aquatic Systems. Sci. Mar. 2004, 68, 13-21. [CrossRef]

39. Manion, P.J. Diatoms as Food of Larval Sea Lampreys in a Small Tributary of Northern Lake Michigan. Trans. Am. Fish. Soc. 1967, 96, 224-226. [CrossRef]

40. Benelli, S.; Bartoli, M.; Racchetti, E.; Moraes, P.C.; Zilius, M.; Lubiene, I.; Fano, E.A. Rare but Large Bivalves Alter Benthic Respiration and Nutrient Recycling in Riverine Sediments. Aquat. Ecol. 2017, 51, 1-16. [CrossRef]

41. Clarke, A.; Johnston, N.M. Scaling of Metabolic Rate with Body Mass and Temperature in Teleost Fish. J. Anim. Ecol. 1999, 68, 893-905. [CrossRef]

42. Samuiloviene, A.; Bartoli, M.; Bonaglia, S.; Cardini, U.; Vybernaite-Lubiene, I.; Marzocchi, U.; Petkuviene, J.; Politi, T.; Zaiko, A.; Zilius, M. The Effect of Chironomid Larvae on Nitrogen Cycling and Microbial Communities in Soft Sediments. Water 2019, 11, 1931. [CrossRef]

43. Wilkie, M.P.; Wang, Y.; Walsh, P.J.; Youson, J.H. Nitrogenous Waste Excretion by the Larvae of a Phylogenetically Ancient Vertebrate: The Sea Lamprey (Petromyzon marinus). Can. J. Zool. 1999, 77, 707-715. [CrossRef]

44. Welsh, D.T.; Castadelli, G. Bacterial Nitrification Activity Directly Associated with Isolated Benthic Marine Animals. Mar. Biol. 2004, 144, 1029-1037. [CrossRef]

45. Staponkus, R.; Kesminas, V. Status Assessment of Lampreys in Natura 2000 Network in Lithuania. Biologija 2014, 60, 1-7. [CrossRef]

46. Geist, J.; Auerswald, K. Physicochemical Stream Bed Characteristics and Recruitment of the Freshwater Pearl Mussel (Margaritifera margaritifera). Freshw. Biol. 2007, 52, 2299-2316. [CrossRef] 